\title{
PERCEPÇÕES DE PROFESSORES SOBRE O USO DE ATIVIDADES LÚDICAS PARA TRATAR O TEMA "ÁGUA E SAÚDE" EM AÇÕES DE EDUCAÇÃO AMBIENTAL NUMA REGIÃO SEMIÁRIDA
}

\author{
M. F. F. ARAÚJO* e A. S. AMORIM \\ Universidade Federal do Rio Grande do Norte \\ magffaraujo@gmail.com*
}

Artigo submetido em março/2013 e aceito em dezembro/2014

DOI: $10.15628 /$ holos.2014.1316

\section{RESUMO}

Estudos sobre Educação Ambiental vêm sendo realizados no sentido de promover um melhor

município de região semiárida brasileira têm sobre o uso entendimento e aperfeiçoamento das práticas de jogos na educação ambiental. Para isso, foram aplicados questionários durante a realização de educativas, com o intuito de despertar nos cidadãos a sensibilização diante dos problemas ambientais alterando, dessa forma, comportamentos individuais e coletivos no cotidiano. O objetivo deste trabalho foi avaliar o uso e os conceitos que os professores de um seminários de divulgação científica e oficinas de jogos educativos. Os resultados apontam que os professores conhecem atividades lúdicas e fazem uso delas, pois reconhecem sua importância para o aprendizado dos alunos, a despeito de isso poder ser intensificado.

PALAVRAS-CHAVE: Atividades lúdicas. Educação Ambiental. Semiárido. Doenças de Veiculação Hídrica.

\section{PERCEPTIONS OF TEACHERS ON THE USE OF RECREATIONAL ACTIVITIES ABOUT "WATER AND HEALTH" DURING ENVIRONMENTAL EDUCATION ACTIONS IN A SEMIARID REGION}

\author{
ABSTRACT \\ Studies on Environmental Education have been done to \\ promote better understanding and improvement of \\ educational practices in order to awaken the public \\ awareness on environmental problems by changing thus \\ individual and collective behavior today. The aim of this \\ study was to evaluate the use and concepts that \\ teachers live in a city located in a semiarid region of
}

Brazil (Caicó-RN) have about the use of games in environmental education using questionnaires during seminars realized to disseminate scientific workshops and educational games. The results show that teachers know recreational activities and use them, and recognize their importance to student learning.

KEYWORDS: Recreational activities. Environmental Education. Semiarid region. Water-Borne Diseases. 


\section{INTRODUÇÃO}

O Rio Grande do Norte é um estado que apresenta grande parte do seu território inserida na região semiárida brasileira, caracterizada pelo clima seco e quente, com chuvas que se concentram nas estações de verão e outono. Essa região representa uma área onde o regime pluvial é irregular, com 400 a $800 \mathrm{~mm}$ anuais. Seus solos são rasos, com ocorrência de vegetação do tipo xerófila, resistente a longos períodos de estiagem (INSA, 2008). As zonas áridas e semiáridas do planeta correspondem a áreas que não possuem água em quantidade suficiente pra satisfazer as variadas demandas de sua população, com características ambientais singulares que as diferenciam de outras (SUASSUNA, 2005).

Essas características, em conjunto, tornam difícil a sobrevivência nessa região e, por isso, uma relação que deve ser estabelecida é aquela existente entre o discurso da convivência com o semiárido e a valorização do local, da diversidade cultural, da recomposição e afirmação de identidades e territórios (SILVA, 2007).

A busca de solução dos problemas relacionados à quantidade e qualidade das águas e sua sustentabilidade para atender os múltiplos usos numa bacia hidrográfica, tornou-se um dos grandes desafios do milênio em curso a ser enfrentado, não apenas pelo poder público, mas pela sociedade civil. A escassez de água na região semiárida exige políticas públicas para minimizar, entre outros problemas, os processos poluidores existentes, causados indiscriminadamente tanto pela população geradora de resíduos, quanto, por exemplo, pelos municípios que dispõem o lixo urbano a céu aberto em margens de rios e rodovias, inadequadamente (BARRETO, 2008).

A Educação Ambiental em bacia hidrográfica está voltada para a gestão participativa dos recursos hídricos, com ênfase nos valores da cidadania, através de ações articuladas entre os implementadores da política e os beneficiários locais na busca de mudança de atitudes, valores e práticas que irão alterar comportamentos individuais e coletivos no cotidiano visando a melhoria da qualidade da água para as populações atuais e futuras. A mudança de percepção sobre a realidade local e a experimentação de alternativas de manejo apropriada pela população é a principal garantia da convivência com a escassez de água do semiárido (BARRETO, 2008; SILVA, 2007).

A Educação Ambiental assume papel importante nesse processo de transformação do pensamento e construção da sociedade. Ela deve integrar conhecimentos, aptidões, valores, atitudes e ações, convertendo cada oportunidade em experiência educativa de sociedades sustentáveis. O princípio de se educar para a saúde e para o ambiente parte da hipótese de que vários problemas de saúde são resultantes da precária situação educacional da população, carecendo, portanto, de medidas corretivas e/ou educativas (ALMEIDA \& SANTOS, 2001; GAZZINELLI et al. 2005).

Segundo Almeida et al. (2004) a Educação Ambiental deve fornecer instrumentos para a sociedade ampliar discussões e ações concretas em relação às questões ambientais de modo a ter uma população, pelo menos no futuro, consciente e educada para tais questões. Para Jacobi (2004) a educação ambiental assume cada vez mais uma função transformadora, onde a coresponsabilização dos indivíduos torna-se um objetivo essencial para promover um novo tipo de desenvolvimento - o desenvolvimento sustentável. 
A proposta principal da Educação Ambiental é a de superar a dicotomia entre natureza e sociedade, através da formação de uma atitude ecológica nas pessoas, ou seja, objetiva a formação de sujeitos capazes de compreender o mundo e agir nele de forma crítica - consciente. Um dos seus fundamentos é a visão socioambiental, que afirma que o meio ambiente é um espaço de relações, é um campo de interações culturais, sociais e naturais (a dimensão física e biológica dos processos vitais) (PGA, 2008).

Muitos educadores e profissionais da comunidade científica têm se engajado nas causas ambientais, e estudos sobre Educação Ambiental vêm sendo realizados no sentido de promover um melhor entendimento e aperfeiçoamento das práticas educativas, com o intuito de despertar nos cidadãos a sensibilização diante dos problemas ambientais.

Segundo Higuchi \& Azevedo (2004) a questão ambiental, mais do que uma palavra em voga, alerta para os diferentes modos que a sociedade humana se relaciona com o meio construído e natural, desde os tempos mais remotos. A preocupação com o meio ambiente passa a ter importância mundial e os esforços para reverter a problemática dá origem a diversas iniciativas, dentre elas a educação ambiental é uma possibilidade que congrega o amplo diálogo, um novo pensar e um novo agir.

Para Janech (2008), a Educação Ambiental é a base para a conscientização que leva à mudança de comportamento dos indivíduos em relação ao meio natural, estabelecendo novos procedimentos e práticas, para a conservação e preservação dos recursos, contribuindo para a construção de uma sociedade sustentável, mais justa e ecologicamente equilibrada. Diniz \& Tomazello (2005) afirmam ainda que as questões ambientais hoje se apresentam como um grande desafio a ser superado e a educação ambiental, muitas vezes, tem sido apontada como a salvadora dos problemas ambientais.

O papel do educador diante das questões ambientais tem destacada importância, pois é por meio da conduta do professor e de sua atuação profissional que as atividades de Educação Ambiental as quais se propõe a fazer terão êxito ou não.

A Educação Ambiental nas escolas deve sensibilizar o professor e o aluno para que construam coletivamente o conhecimento por meio de estratégias pedagógicas de mudança de mentalidade (ALMEIDA et al., 2004) e a participação dos professores no processo do ensino depende de sua formação profissional e interesse pela temática ambiental, sendo um constante desafio sua atualização pedagógica e científica.

O educador deve ser uma pessoa que respeite o que os educandos pensam e o que eles fazem, mesmo tendo conhecimento de que a forma como eles agem pode trazer problemas para eles mesmos (Higuchi e Azevedo (2004). Nesse contexto, a Educação Ambiental é um tema que pode ser desenvolvido em múltiplas experiências metodológicas em diversos níveis de abrangência. Em qualquer dos casos cabe ao educador, por intermédio de sua vivência pessoal e profissional, propor metodologias que favoreçam a construção da cidadania ambiental.

Algumas experiências cotidianas, visando promover Educação Ambiental, vêm sendo realizadas em parques, reservas ecológicas, praças públicas e em outros locais de fácil acesso e que estejam relacionados ao meio ambiente. Essas atividades apresentam resultados satisfatórios, o que mostra que os alunos aprendem melhor se o assunto abordado for relacionado ao seu cotidiano. Segundo Diniz \& Tomazello (2005) é importante que a 
aprendizagem seja significativa para o aluno, que os conteúdos sejam trabalhados de forma mais contextualizada, ampla, superando a fragmentação dos conhecimentos e introduzindo um trabalho de modo interdisciplinar.

Os jogos são estratégias lúdicas e prazerosas de aprendizado, pois através deles os estudantes têm a oportunidade de interagir entre si além de desenvolverem habilidades cognitivas importantes para o processo de aprendizagem, tais como: resolução de problemas, percepção, criatividade, raciocínio rápido, entre outras habilidades. Se o jogo, desde seu planejamento, for elaborado com o objetivo de atingir conteúdos específicos e para ser utilizado no âmbito educacional pode-se denominá-lo de jogo didático. Nos jogos educacionais não existem perdedores, todos são beneficiados com o aprendizado, que se adquire com a integração com o jogo (AMORIM et al., 2008; ZANON et al., 2008).

Jacobi (2004) acredita que a produção de conhecimento deve necessariamente contemplar as inter-relações do meio natural com o social, incluindo a análise dos determinantes do processo, o papel dos diversos atores envolvidos e as formas de organização social que aumentam o poder das ações alternativas de um novo desenvolvimento, numa perspectiva que priorize um novo perfil de desenvolvimento, com ênfase na sustentabilidade socioambiental.

Diante da importância que as questões ambientais tomaram nas últimas décadas e das dificuldades encontradas na região semiárida, o objetivo deste trabalho foi avaliar o uso e os conceitos que os professores de um município do Rio Grande do Norte têm sobre o uso de jogos para o desenvolvimento de atividades em educação ambiental.

\section{PERCURSO METODOLÓGICO}

Para efeito deste trabalho duas atividades principais foram realizadas: a primeira foi a divulgação de dados sobre a qualidade da água do reservatório da cidade de Caicó (Itans) em um seminário apresentado na comunidade escolar, e a outra foi a aplicação e análise de questionários em uma oficina sobre jogos didáticos.

\subsection{Atividades de Divulgação científica}

Para divulgar os dados referentes à qualidade da água do reservatório Itans, que se localiza na cidade de Caicó, RN, foram apresentados os resultados de um estudo sobre o diagnóstico sócio-ambiental do município. O intuito dessa divulgação foi atentar os professores sobre o seu papel na formação de uma nova sociedade sensível e solidária com os problemas ambientais.

\subsection{Aplicação de questionários e amostragem}

O presente estudo teve como instrumento de coleta de dados dois questionários elaborados com questões abertas para os professores responderem, cada um contendo três questões, todas relacionadas a atividades lúdicas para melhoria das aulas.

As vantagens de se aplicarem questionários abertos é que eles possibilitam maior liberdade de resposta, pois esta pode ser redigida pelo próprio questionado, e proporciona respostas de maior profundidade, o que a primeira vista pode ser visto como uma dificuldade 
para posterior interpretação, mas ao mesmo tempo esse tipo de questão oferece respostas mais representativas e fiéis da opinião do questionado e permite recolher variada informação sobre o tema em questão (BONI \& QUARESMA, 2005).

Os questionários foram aplicados durante a realização de uma das etapas do Projeto "Mergulhando na Ciência", que é um programa de divulgação científica que utiliza o tema água para sensibilização sobre os problemas ambientais locais, neste caso, na cidade de Caicó, Rio Grande do Norte. Informações profissionais também foram solicitadas nos questionários tais como formação acadêmica e disciplinas de atuação. Os professores responderam ao questionário no local onde foram realizadas as atividades.

A aplicação dos questionários foi dividida em dois momentos: antes de se desenvolverem os trabalhos com jogos e brincadeiras para serem utilizados em sala de aula e ao final dessas atividades. Ao primeiro questionário 20 professores responderam e ao segundo 26 , totalizando 46 questionários respondidos, porém apenas 40 questionários foram considerados válidos, ou seja, aqueles em que o mesmo professor respondeu aos dois, em cada momento de aplicação.

\subsection{Desenvolvimento de Jogos didáticos}

Para atender a proposta de atividades lúdicas a serem trabalhadas em sala de aula pelos professores, três jogos foram confeccionados: o Jogo da Memória, Baralho Didático e Detetive Aquático. Estes jogos serão apresentados brevemente, a seguir, lembrando que não é intenção deste trabalho avaliá-los, mas sim a sua utilização, pelos professores, como atividades lúdicas no ensino de ciências.

O Jogo da Memória teve duas versões: o primeiro (Jogo da Memória - Doenças de Veiculação Hídrica) apresentava doze pares de cartas que representam doenças de veiculação hídrica e seus organismos causadores por meio de figuras; já o segundo (Jogo da Memória - Água e Saúde) também apresentava doze pares de doenças, seu agente causador e seus respectivos modos de transmissão. O objetivo do jogo é reunir o maior número de pares de doenças (cartas) antes dos demais jogadores. O jogo deve ter no mínimo dois participantes e no máximo seis.

O Baralho Didático é formado por 60 cartas que tratam de doze doenças de veiculação hídrica (cólera, dengue, disenteria bacteriana, disenteria amebiana, esquistossomose, febre tifóide, filariose, giardíase, hepatite A, leishmaniose e poliomielite). As doenças foram divididas em cinco categorias de cartas que retratam curiosidades a respeito da doença, seus sintomas, o modo de transmissão, os sintomas decorrentes de cada uma, seus agentes transmissores e, por último, cura (quando existir) e prevenção. O objetivo do jogo é reunir o conjunto de cinco cartas relacionadas a uma determinada doença de veiculação hídrica de sua própria escolha. Pode ser jogado por no mínimo três e no máximo doze jogadores.

O jogo do Detetive Aquático é constituído por 01 tabuleiro, 01 dado, 19 cartas, 01 envelope, 05 blocos de anotações e 05 peões e deve ter de três a cinco jogadores. As cartas representam cinco doenças suspeitas, cinco sintomas apresentados e nove locais da cidade. As cartas das doenças trazem também os seus agentes etiológicos e os vetores (quando é o caso) de cada uma delas. As doenças retratadas no jogo são: cólera, dengue, disenteria bacteriana, disenteria amebiana e esquistossomose. Os sintomas são: febre; diarréia; dor de cabeça; náuseas e vômitos; e dor abdominal. Os locais da cidade representados são: reservatório, biblioteca, casa, escola, hospital, igreja, padaria, praça e zoológico. Vence o jogo aquele que conseguir descobrir, 
antes dos demais jogadores, três informações a respeito de uma pessoa que foi infectada por uma doença de veiculação hídrica em uma determinada cidade fictícia.

\section{RESULTADOS E DISCUSSÃO}

\subsection{Divulgação científica}

Durante o seminário de divulgação dos dados foram apresentadas palestras sobre conceitos importantes ligados a qualidade de água, tais como coliformes fecais e variáveis abióticas (concentrações de nutrientes, pH, temperatura e oxigênio dissolvido). Os professores mostraram-se bastante participativos levantando várias questões pertinentes ao assunto. A discussão do tema revelou que as pessoas têm consciência da necessidade da população local se importar mais com os problemas encontrados no reservatório, demonstrando grande interesse em saber se há medidas que possam reverter esse quadro. Os resultados do diagnóstico sócioambiental foram associados com práticas de origem antropogênicas que provavelmente estão influenciando na má qualidade da água do reservatório.

Atividades desse tipo constituem uma contribuição importante no conhecimento, pela população, da qualidade da água em regiões que apresentam déficit hídrico. Atividades semelhantes vêm sendo desenvolvidas há algum tempo (ARAUJO et al., 2006). Almeida et al. (2004) também realizaram atividade semelhante por meio de oficinas para professores do ensino fundamental com a finalidade de elaborar uma proposta de Educação Ambiental em uma praça pública no centro histórico da cidade de Botucatu, no estado de São Paulo. Tais oficinas basearam-se em informações sobre o município e informações botânicas da Praça Rubião Júnior, em Botucatu. Experiências dessa natureza têm-se revelado de extrema importância, pois servem como um estímulo para alunos e educadores se engajarem nas causas sociais visando a melhoria do meio ambiente.

Atividades de divulgação científica por meio de palestras e propostas pedagógicas inovadoras e simples vêm sendo de grande valia para o que propõe a Educação Ambiental, pois despertam o interesse das pessoas envolvidas sobre as questões ambientais levando em conta os problemas locais e as soluções mais adequadas, de acordo com a cultura e a história da região.

\subsection{Atividades lúdicas desenvolvidas com professores}

\subsubsection{O Perfil dos professores}

A faixa etária dos professores esteve entre 26 e 60 anos, tendo a grande maioria idade entre 35 e 45 anos (45\%) (figura 2), ou seja, são professores experientes na profissão, com a maioria (65\%) tendo entre 5 e 15 anos de experiência profissional. 


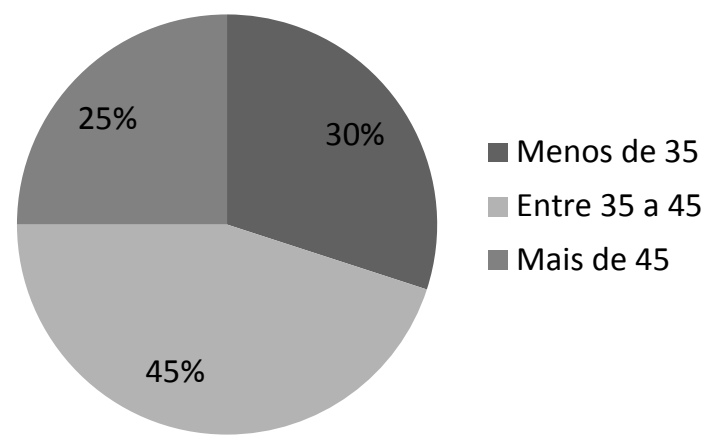

Figura 2 - Percentual da faixa etária dos professores.

Dos professores participantes $84 \%$ eram do sexo feminino. A formação acadêmica da maioria é em pedagogia (65\%) e 50\% deles atuam como professores polivalentes (figura 3 ). 0 fato de a maioria dos professores trabalharem como profissionais polivalentes pode ser considerado uma vantagem para se fazer Educação Ambiental, uma vez que ela propõe que o ensino deve ser interdisciplinar, pois só com o envolvimento de várias áreas do conhecimento é possível se ter uma noção mais elaborada das questões ambientais.

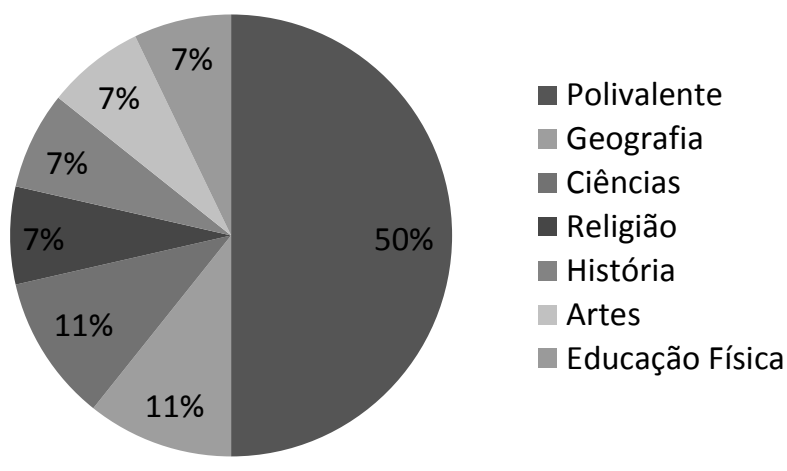

Figura 3 - Percentual das disciplinas lecionadas pelos professores questionados.

\subsubsection{As atividades lúdicas}

A primeira questão objetivava saber se os professores realizavam atividades diferentes para melhorar as aulas e, caso realizassem, quais atividades eram essas. A maioria dos professores (85\%) afirmou fazer uso de atividades desse tipo. As atividades especialmente citadas foram jogos, brincadeiras e mamulengos (figura 4). 


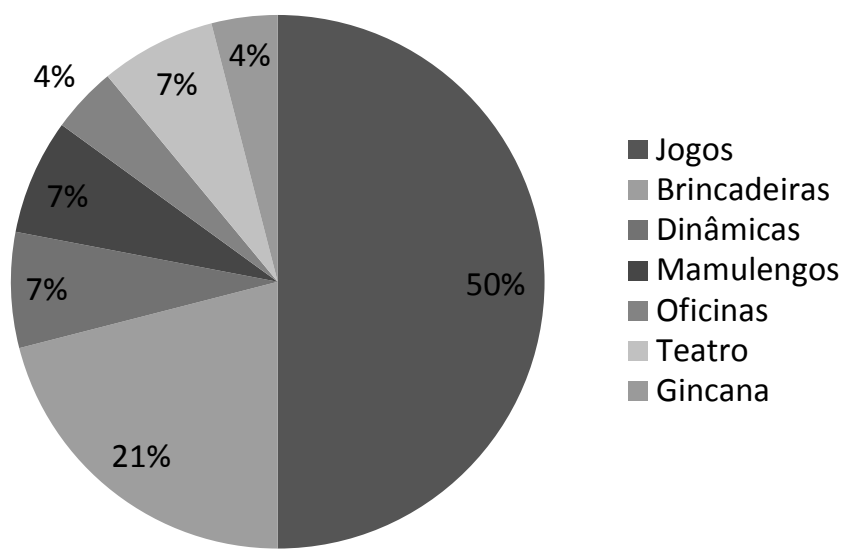

Figura 4 - Atividades lúdicas citadas pelos professores.

A segunda questão era direcionada aos professores que responderam que não realizavam nenhuma atividade lúdica em sala de aula e procurava saber o motivo disso. Apenas três professores responderam não à primeira questão e cada um apresentou uma resposta diferente para a segunda questão. Um dos professores afirmou que esse tipo de atividade "foge do assunto", outro que acha mais interessante a aula de vídeo, campo ou pesquisa e um deles justificou que não conhece nenhum material para desenvolver essas atividades.

A terceira questão buscou saber a opinião dos professores sobre as vantagens de atividades dessa natureza. A vantagem de facilitar o aprendizado foi a mais citada (29\%), seguida de melhoria no aprendizado (25\%), tornar a aula mais agradável (18\%), motivar os alunos por meio da participação e envolvimento deles durante as aulas (11\%), aumentar o interesse dos alunos (10\%) e estimular o trabalho em equipe $(7 \%)$.

O estudo mostrou que a maioria dos professores busca melhorias em suas aulas por meio de atividades que as dinamizem tornando-as mais agradáveis e que eles sabem da importância de atividades dessa natureza para o aprendizado e o interesse dos alunos. Também pode-se perceber que ainda existem professores que acreditam que a maneira tradicional de se ensinar é a melhor, justificando que aulas onde se buscam métodos novos dispersam a atenção dos alunos.

O fato de os professores terem citado frequentemente o teatro de bonecos (mamulengo) entre as atividades mais desenvolvidas por eles em sala de aula chama atenção, uma vez que essa é uma prática bem regional, revelando que a cultura local vem sendo levada em consideração na elaboração de aulas de ciências, o que deve torná-las mais significativas para os alunos.

\subsubsection{Aplicação dos jogos}

Todos os jogos visaram relacionar, de um modo geral, a qualidade e o ciclo da água com o cotidiano da comunidade e as suas implicações na saúde humana, e essa relação foi aprofundada durante a palestra anteriormente realizada. A aplicação dos jogos transcorreu de maneira tranqüila e houve participação e envolvimento de todos os professores nas atividades propostas. Os professores se mostraram interessados em aprender como jogá-los corretamente e em entender algumas questões referentes à qualidade de água abordada em alguns jogos, pois eles naturalmente levam a que se discuta a esse respeito durante cada partida. No desenvolvimento 
da atividade, cada grupo era incentivado a buscar soluções para cada doença de veiculação hídrica ou problema ambiental tratados pelos jogos, no sentido de que se pensasse uma maneira de prevenir o problema na cidade de cada jogador.

O Jogo Água e Saúde, por ser o mais simples de se jogar e entender, pode ser facilmente aplicado no ensino fundamental. Os outros jogos, que exigem um maior conhecimento, são considerados mais adequados para o ensino médio e estão disponíveis no site do projeto mergulhando na ciência: www.cb.ufrn/mergulhandonaciencia. A figura 5 mostra os jogos "Água e saúde" (A) e "Baralho Didático" (B).
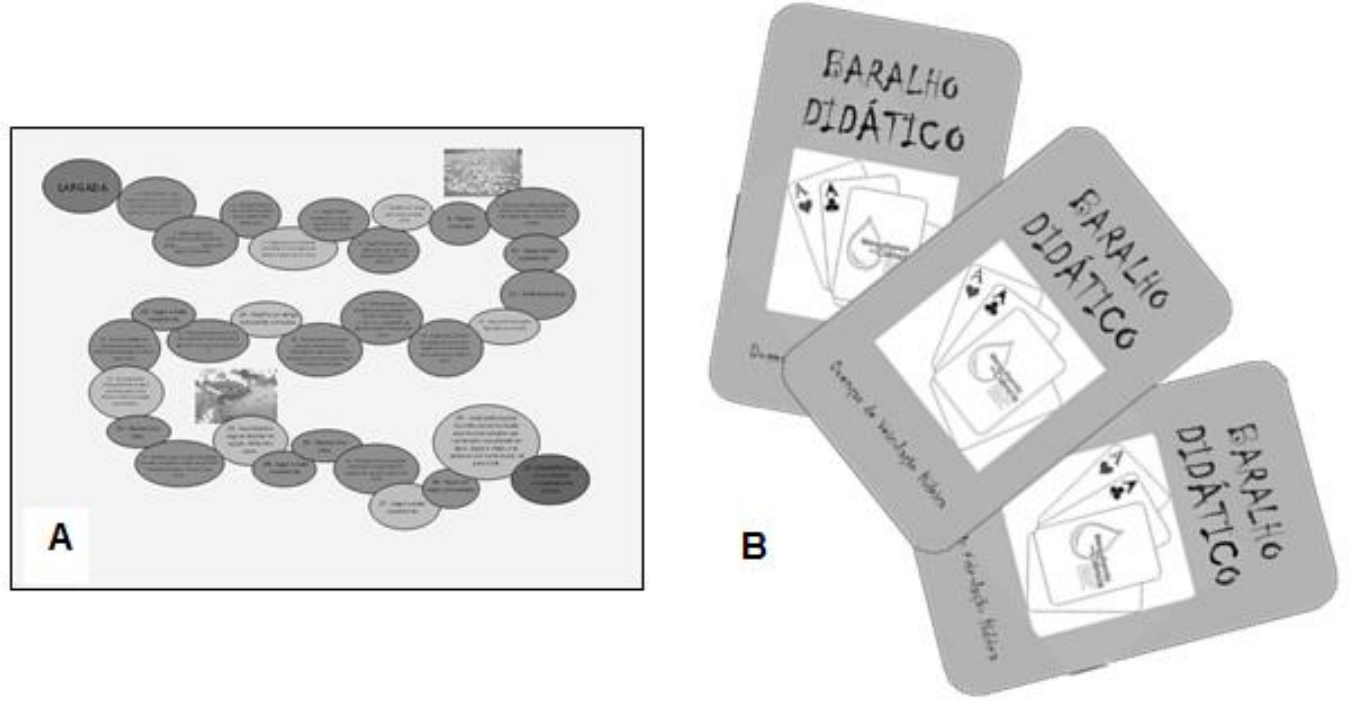

Figura 5 - Jogos “Água e saúde” (A) e "Baralho Didático” (B).

\subsubsection{A opinião dos professores sobre os jogos}

A primeira pergunta dos questionários aplicados logo após as apresentações das atividades lúdicas objetivou saber se os professores utilizariam alguma das atividades propostas para se trabalhar o tema "qualidade de água" e solicitava que justificassem suas respostas. Responderam afirmativamente $80 \%$ dos professores. As justificativas mais citadas para a utilização das metodologias pedagógicas apresentadas foram: "facilita o aprendizado", "é uma nova metodologia para se aplicar em sala de aula", "contribui para o aprendizado do aluno", "torna a aula mais prazerosa", "são metodologias criativas", "orienta o professor em sala de aula", "transforma teoria em prática", "estimula o trabalho em equipe por parte dos alunos" e “chama a atenção do aluno para a aula" (figura 5). 


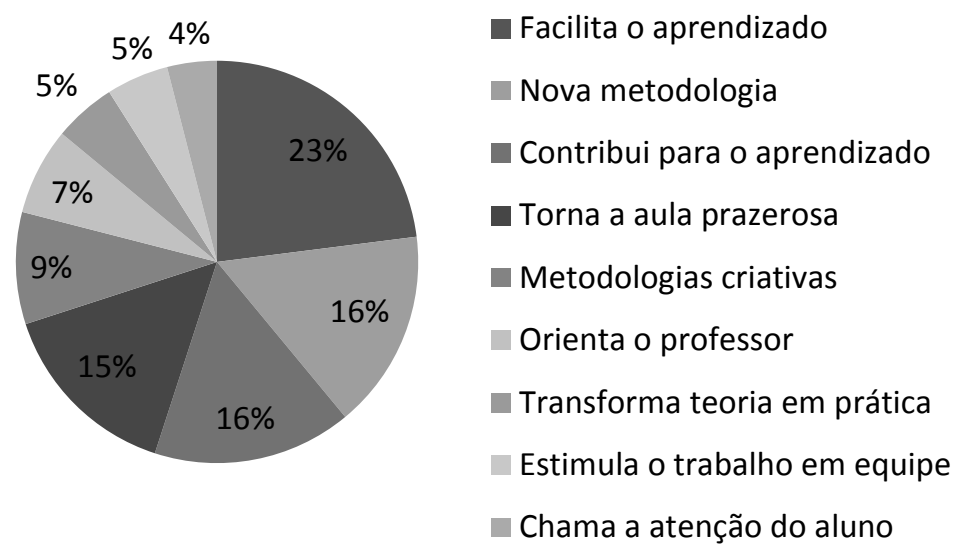

Figura 6 - Percentual das justificativas dos professores para o uso de atividades lúdicas.

A segunda questão foi sobre quais jogos, dos que foram apresentados, os professores utilizariam em sala de aula. A ordem de preferência dos professores foi: Jogo da Memória (41\%), Baralho Didático (23\%) e Detetive Aquático (20\%). Ainda na mesma questão 16\% dos professores disseram que utilizariam todos. Apenas um professor respondeu que ainda não utilizaria nenhum dos jogos apresentados porque necessitaria de mais prática para poder usá-los.

A terceira questão procurou saber se os professores tinham alguma sugestão para os jogos apresentados. $40 \%$ dos professores afirmaram não ser necessário modificar nada em nenhum dos jogos apresentados, pois todos eram muito bons; $24 \%$ sugeriram oficinas para a confeç̧ão dos jogos pela própria escola; $13 \%$ acharam que é necessário adaptar os jogos para o nível fundamental; $13 \%$ sentiram falta de regras que acompanhassem os jogos, embora as regras tenham sido apresentadas, no inicio dos trabalhos; $5 \%$ sugeriram que, em outras oficinas, fosse dado mais tempo para aplicação dos jogos e $5 \%$ reclamaram da necessidade de mais suporte às escolas por parte da UFRN.

Os resultados encontrados a partir desse questionário mostram que a maioria dos professores sente a necessidade de conhecer novas metodologias para se trabalharem em sala de aula, pois sabe que elas são essenciais para tornar as aulas mais dinâmicas, uma vez que promovem o envolvimento dos alunos, facilitando assim o aprendizado deles. Também foi possível observar que os professores gostariam de ter mais oportunidades como a desse trabalho para conhecerem alguns jogos e desenvolverem os seus próprios a partir da realidade deles.

Na realidade, muitos programas de educação ambiental na escola são implementados de modo reducionista (LAYARGUES, 2002), sem proporcionarem uma reflexão crítica e abrangente a respeito dos valores culturais da sociedade de consumo, do consumismo, e do modo de produção capitalista, o que não é salutar.

Os jogos apresentados durante as atividades tiveram uma ampla aceitação e as sugestões que os professores fizeram foram importantes, no sentido de que permitiram uma adequação posterior dos jogos para alunos do ensino fundamental, utilizando uma linguagem mais simplificada. Nessa perspectiva, devem ser envidados esforços para que os programas envolvidos visem à educação e a sensibilização e não o simples treinamento, pois só assim será possível fazer com que as pessoas passem a pensar na solidariedade e ajuda mútua como formas de gerar 
e fortalecer ações ambientalmente sustentáveis (Bezerra e Gonçalves 2007), e o planejamento de ações continuadas é que vai garantir isso.

\section{CONSIDERAÇÕES FINAIS}

As atividades de divulgação científica e de novas propostas educativas que dinamizem as aulas vêm sendo apontadas como ferramentas importantes para a Educação Ambiental e essas práticas tiveram efeitos positivos quando trabalhadas com professores da rede pública no município de Caicó. A realização desse tipo de proposta que se utiliza de participação ativa dos estudantes como sujeitos protagonistas do processo ensino aprendizagem se revelou positiva, tanto em aspectos cognitivos, associados à aprendizagem do conteúdo específico, quanto no que diz respeito ao envolvimento e à motivação para a aprendizagem.

Durante as palestras ministradas foi possível observar que os professores conhecem os problemas ambientais do seu município e sabem que eles podem interferir nessa realidade. Além disso, eles se mostraram abertos às propostas educativas apresentadas e interessados em fazer uso delas em sua prática docente.

Metodologias alternativas e a elaboração de atividades lúdicas como jogos didáticos, os quais permitem a integração entre teoria e prática e a diversificação no ato de ensinar e aprender, devem ser valorizadas e estimuladas pelas instituições de ensino básico, uma vez que tornam mais efetivas o envolvimento do aluno com o tema em estudo, possibilitando uma aprendizagem mais concreta, uma vez que provocam uma motivação para a apreensão do conhecimento, o qual se torna significativo.

O trabalho revelou que a maioria dos professores conhece atividades lúdicas e faz uso delas para tornar suas aulas mais interessantes, pois sabem da sua importância para o aprendizado dos alunos. Também ficou claro que os professores gostariam que atividades dessa natureza fossem realizadas mais vezes, como uma forma de atualização do conhecimento e do desenvolvimento de novas práticas educativas.

\section{REFERÊNCIAS BIBLIOGRÁFICAS}

1. ALMEIDA, L. F. R.; BICUDO, L. R. H.; BORGES, G. L. A. Educação ambiental em praça pública: relato de experiência com oficinas pedagógicas. Ciência \& Educação, Bauru, v. 10, n. 1, p. 121-132, 2004.

2. ALMEIDA, M. T.; SANTOS, A. C. K. Um estudo com alunos do ensino fundamental de Rio Grande, sobre problemas sócio-ambientais no entorno da escola, tendo como base a modelagem semiquantitativa: resultados parciais. Rev. Eletrônica Mestr. Educ. Ambient.. Rio Grande, v. Esp., p. 199-216, 2001.

3. AMORIM, F. D. B.; AMADOR, D. D.; MARINHO, A. H.; ALMEIDA, R. A.; ROSALMEIDA, M. D. P.; FARIAS, L. X. N.; CARVALHO, L. L. F.; SOUSA, J. O.; NOGUEIRA, R. B. S. S.; LIMA, C. M. B. L.; ALENCAR, V. M. P. D. Aprender e ensinar parasitologia brincando. In.: Anais do XI Encontro de Iniciação à Docência, João Pessoa/PB, 2008.

4. ARAÚJO, M. F. F.; PANOSSO, R. F.; COSTA, I. A. S. Ações em educação ambiental visando a sensibilização dos moradores da cidade de Jardim de Piranhas para a preservação do Rio 
Piranhas (RN). Revista Educação Ambiental em ação, v. 18, p. 5-6, set-nov/2006.

5. BARRETO, I. M. C. B. N. Educação Ambiental em bacia hidrográfica e o saneamento. Meio Ambiente - Cursos Online - Educação e Gestão Ambiental - CENED, disponível em: http://www.cenedcursos.com.br. Acesso em: 22 de agosto de 2008.

6. BONI, V.; QUARESMA, S. J. Aprendendo a entrevistar: como fazer entrevistas em Ciências Sociais. Revista Eletrônica dos Pós-Graduandos em Sociologia Política da UFSC. v. 2, n. 1, p. 68-80, 2005.

7. DINIZ, E. M.; TOMAZELLO, M. G. C. A pedagogia da complexidade e o ensino de conteúdos atitudinais na educação ambiental. Revista eletrônica do Mestrado em Educação Ambiental, Rio Grande, v. 15, p. 80-93, jul./dez. 2005.

8. GAZZINELLI, M. F.; GAZZINELLI, A.; REIS, D. C.; PENNA, C. M. M. Educação em saúde: conhecimentos, representações sociais e experiências da doença. Cadernos de Saúde Pública, Rio de Janeiro, v. 27, n. 1, p. 200-206, 2005.

9. INSA. Instituto Nacional do Semi-árido. Disponível em: http://www.insa.gov.br. Acesso em: 06 de jun. de 2008

10. HIGUCHI, M. I. G.; AZEVEDO, G. C. Educação como processo na construção da cidadania ambiental. Revista Brasileira de Educação Ambiental, Brasília, n. 0, p. 63-70, nov. 2004.

11. JACOBI, P. Educação e meio ambiente - transformando as práticas. Revista Brasileira de Educação Ambiental, Brasília, n. 0, p. 28-35, nov. 2004.

12. JANECH, M. A. Meio Ambiente: recursos hídricos. Centro Nacional de Educação a Distância, Porto Alegre. Disponível em: http://www.cenedcursos.com.br. Acesso em: 21 jun. 2008.

13. PGA. Programa de Gestão Ambiental: Procuradoria Geral da República. Disponível em: http://pga.pgr.mpf.gov.br. Acesso em: 05 jul. 2008.

14. LAYARGUES, P. O cinismo da reciclagem: o significado ideológico da reciclagem da lata de alumínio e suas implicações para educação ambiental, p. 179-220. In: Loureiro, F.; Layargues, P.; Castro, R. Educação ambiental: repensando o espaço da cidadania. São Paulo, Cortez. (2002).

15. SEMARH. Secretaria de Estado do Meio Ambiente e dos Recursos Hídricos. Disponível em: http://www.semarh.rn.gov. Acesso em: 06 de jun. de 2008.

16. SILVA, R. M. A. Entre o Combate à Seca e a Convivência com o Semi-Árido: políticas públicas e transição paradigmática. Revista Econômica do Nordeste. Fortaleza, v. 38, n. 3, p. 466-485, 2007.

17. SUASSUNA, J. Potencialidades Hídricas do Nordeste Brasileiro. Parcerias Estratégicas. n. 20, p. 119-144, 2005.

18. ZANON, D. A. V.; GUERREIRO, M. A. S.; OLIVEIRA, R. C. Jogo didático Ludo Químico para o ensino de nomenclatura dos compostos orgânicos: projeto, produção, aplicação e avaliação. Ciências \& Cognição, v. 13, n. 1, p. 72-81, 2008. Disponível em: http://www.cienciasecognicao.org/pdf/v13/cec_v13-1_m318239.pdf. Acesso em: 19 de jan. de 2010. 